\title{
Assessment of Optimum Salinity Level for Maximum Growth and Survival of Nile Tilapia, Oreochromis niloticus (Linnaeus 1758)
}

\author{
Abdul Malik ${ }^{1,2}$, Ghulam Abbas ${ }^{1 \%}$, Abdul Ghaffar ${ }^{3}$, Ghulam Dastagir ${ }^{4}$, \\ Sara Ferrando ${ }^{5}$, Lorenzo Gallus ${ }^{5}$, Asad Ali Muhammad ${ }^{1,6}$, Abdul Jabbar ${ }^{2}$ \\ and Khalil-ur-Rehman ${ }^{2}$ \\ ${ }^{1}$ Centre of Excellence in Marine Biology, University of Karachi, Karachi \\ ${ }^{2}$ Livestock and Fisheries Department, Directorate of Fisheries Sindh, Govt. of \\ Sindh, Karachi \\ ${ }^{3}$ Department of Life Sciences, The Islamia University of Bahawalpur, Bahawalpur \\ ${ }^{4}$ Department of Zoology, University of Baluchistan, Quetta \\ ${ }^{5}$ Department of Earth, Environment and Life Sciences, University of Genoa, Italy \\ ${ }^{6}$ Coastal Development and Fisheries Department, Government of Baluchistan, \\ Quetta

\section{A B S T R A C T} \\ Assessment of optimum salinity level (10\%o, 15\%o, 20\%o, 25\%o and 30\%o) for $\&$ wth perfompance, food \\ conversion, body composition and survival rate of Nile tilapia, Oreochromis nilo s (mear pdy weight \\ $4.5 \pm 0.5 \mathrm{~g}$ ) were investigated. Fingerlings were randomly distribut to the glas $10 \times 30 \times 45$ \\ $\mathrm{cm}$ each). Ten fish per tank were stocked with two replications. Fis \\ pellet (35\% protein) with $3 \%$ of total biomass day ${ }^{-1}$ for 50 days. Resul ho the growth increment \\ reared on $10 \%-20 \%$ salinity were significantly highes $m$ of we gain, $w^{2} \%$ of initial weight, \\ daily weight gain, specific growth rate, condition or an surviva te than those reared on $25 \%$ \\ and 30\%. Feed conversion ratio was found similar 11 not significantly different $(P>$
} $0.05)$. Whole body composition i.e. protein $8.16 \%$. $20 \%$ oisture $(71.16 \%-71.26 \%)$, lipids $(2.49 \%-2.52 \%)$, ash $(4.16 \%-4.18 \%$ ents of fis hole body were not significantly $(P>0.05)$ different at varying salinity levels. Meni va of water dity were found acceptable for tilapia i.e. temperature $28.42 \pm 0.08^{\circ} \mathrm{C}$, diss ${ }^{\prime}$ a oxygen $7.0 .06 \mathrm{mg} / \mathrm{L}, \mathrm{pH} 7.64 \pm 0.04$ and ammonia $0.022 \pm 0.004$ $\mathrm{mg} / \mathrm{L}$. Relationship between oody weight and total length of the the fish shows that Nile tilapia fingerlings reared from 10\%o $0 \%$ significantly $(P<0.05)$ higher than $25 \%$ and $30 \%$ salinity levels. Present study suggests that $\mathrm{Ni}_{\text {apia }}$ cap'se reared up to $20 \%$ salinity to get good growth and higher survival rate.

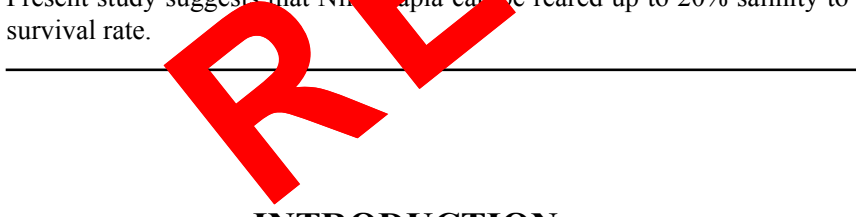

\section{INTRODUCTION}

$\mathrm{S}$

alinity is one of the environmental factors which affect $\checkmark$ the growth performance of several fish species reared in ponds, tanks, raceways, and net-cages (Cruz et al., 1990; Watanabe et al., 1990; Naylor et al., 2000; Cressey, 2009; Ferreira et al., 2009; Martins et al., 2010; FAO, 2014; Cao et al., 2015; OECD/FAO, 2015). Salt control in these culture systems is a serious task for maintaining life in all higher organisms like bony fish including tilapia or cichlids.

\footnotetext{
Corresponding author: ghulamabbas@uok.edu.pk 0030-9923/2018/0002-0585 \$ 9.00/0

Copyright 2018 Zoological Society of Pakistan
}

Similarly, salt acceptance defines a complete fitness or production of fish in a saline atmosphere (Cnaani and Hulata, 2011). Several cichlids have shown curiously acceptance in brackish water or seawater environment for growing and even for breeding in sea water (Kamal and Mair, 2005; El-Syed, 2006; Parry, 2007; Lawson and Anetekhai, 2011; Sallam et al., 2017). Due to shortage of freshwater in the biosphere, it would be helpful to raise tilapia stocks in brackish or seawater environments to certify a source of low-priced and high-quality protein (animal origin) for future (Mateen and Iftikhar, 2017; Hassan et al., 2013; Sallam et al., 2017).

Euryhaline species of tilapia can be found in saline water adjacent to the rivers (Barlow, 2000; Nelson, 2006; 
Cnaani and Hulata, 2011). A few tilapias are found primarily in saline or pure sea water, particularly Sarotherodon melanotheron (Jeanette et al., 2007; Cnaani and Hulata, 2011). They have gained prolonged popularity, and confidently tilapia hybrids/cross-breed can grow in saline and pure sea water (Kamal and Mair, 2005; Sakamoto and McComick, 2006; Mancera and McCoemick, 2007; Lim and Webster, 2008; Kang'ombe and Brown, 2008; Cnaani and Hulata, 2011; Lawson and Anetekhai, 2011; Fitzsimmons, 2016; Sallam et al., 2017). They are hardy, productive and fast growing warm-water fishes. They have short food chain and are recognized as adaptable and herbivorous which mostly eat plankton (zooplankton and phytoplankton), algae, aquatic macrophytes and other plant substances (Cnaani and Hulata, 2011; Ng and Romano, 2013; Saikia and Das, 2015). Therefore, tilapias support to reduce pressure on capture fisheries by rearing intensively (Yue et al., 2016; Sallam et al., 2017). Production response of several breeds and strains of tilapia have been significantly improved through breeding (Dey, 2000; Ponzoni et al., 2011; Fitzsimmons, 2016; Nguyen, 2016). In addition, tilapias have also been cultured successfully in saline areas of 120 countries and is strongly suggested as future fish for brackish water aquaculture (Wassmann et al., 2004; Fitzsimmons, 2016; Lim and Webster, 20

Nile tilapia (Oreochromis niloticus) have good position among the most sophisticated species in severa parts of the world (Lawson and Anetekha1, 2011; Hernandez et al., 2014). It has been successfully reared under an extensive variety of natura conditions, especially in saline areas of tropical and sub-tropical countries (Stickney, 1986; El-Sayed, 2002; Lawson and Anetekhai, 2011; Githukia et al,2014; Ogello et at., 2014; Siddik et $a l, 2014)$. But the data is scarce on its growth and survival with regard to the optimal salt tolerance for sustainable aquaculture in underground saline water or in coastal areas (Parry, 2007, Mateen and Iftikhar, 2007; Abdel-Tawwab, 2011; Hassan et al. 2013; Sallam et al., 2017). The present research reports optimal salinity level for best growth, feed intake efficiency, tolerance and maximum survival rate of
Nile tilapia in controlled conditions.

\section{MATERIALS AND METHODS}

\section{Experimental design}

Fingerlings of Nile tilapia, O. niloticus (mean body weight $4.5 \pm 0.05 \mathrm{~g}$ and mean total length $6.2 \pm 0.4 \mathrm{~cm}$ ) (Table I) procured into the aquaculture research laboratory, CEMB, University of Karachi. They were acclimated for one week and then treated with different salinity levels i.e. $10 \%$, $15 \%$ o, $20 \%$, $25 \%$ and $30 \%$ with two replications (10 fingerlings per tank) having size $60 \times 30 \times 45 \mathrm{~cm}$. All tanks were well aerated throughout the experiment.

\section{Feeding protocol}

Commercial floating pelleted feed manufactured by Oryza Organics Private Limited, Lahore, Pakistan, having $35 \%$ crude protein, $5.8 \%$ crude fat, $6.7 \%$ crude fiber, $9.8 \%$ moisture and $8.4 \%$ ash was offered at $3 \%$ of total biomass 2 time in a day, morning 9:00 and evening . Body weight and total length of individual fish was neasured weekly basis and the amount of provided feed s adjusted accordingly. Siphoning was done after $1 \mathrm{~h}$ feeding to remove waste material from the tanks bottom and sea water was added to maintain the required water Yevel.

\section{Measurement and analysis}

At the end of the experiment, all fish from each tank were individually weighed and their total length was measured for calculation of biological data including weight gain, percent weight gain of initial body weight, feed conversion ratio, condition factor, specific growth rate and survival (Abbas et al., 2011; Daudpota et al., 2016). Water quality parameters like temperature, $\mathrm{pH}$, dissolved oxygen and ammonia were monitored throughout the experimental period. Temperature of the water was checked on daily basis with the help of digital thermometer (GH Zeal LtdLondon England).

Table I.- Initial and final weight and length of Nile tilapia (Oreochromis niloticus) reared on different salinity levels for 50 days.

\begin{tabular}{lccccc}
\hline Parameters & \multicolumn{3}{c}{ Salinity level (\%o) } \\
\cline { 2 - 6 } & $\mathbf{1 0}$ & $\mathbf{1 5}$ & $\mathbf{2 0}$ & $\mathbf{2 5}$ & $\mathbf{3 0}$ \\
\hline Initial weight (g) & $4.5 \pm 0.06$ & $4.5 \pm 0.5$ & $4.5 \pm 0.6$ & $4.5 \pm 0.5$ & $4.5 \pm 0.6$ \\
Final weight (g) & $16.1 \pm 0.5$ & $16 \pm 0.7$ & $15.9 \pm 0.4$ & $9.3 \pm 0.7$ & $6.6 \pm 0.5$ \\
Initial length (cm) & $6.24 \pm 0.3$ & $6.24 \pm 0.4$ & $6.24 \pm 0.5$ & $6.24 \pm 0.4$ & $6.25 \pm 0.3$ \\
Final length (cm) & $11.5 \pm 0.2$ & $11.4 \pm 0.3$ & $11.3 \pm 0.3$ & $8.6 \pm 0.4$ & $7.1 \pm 0.3$ \\
Weight gain (WG) & $11.6 \pm 0.04$ & $11.5 \pm 0.07$ & $11.4 \pm 0.05$ & $4.8 \pm 0.07$ & $2.1 \pm 0.05$ \\
\hline
\end{tabular}

Values of the same row carrying the same superscripts are not statically significant $(\mathrm{P}>0.05)$. 

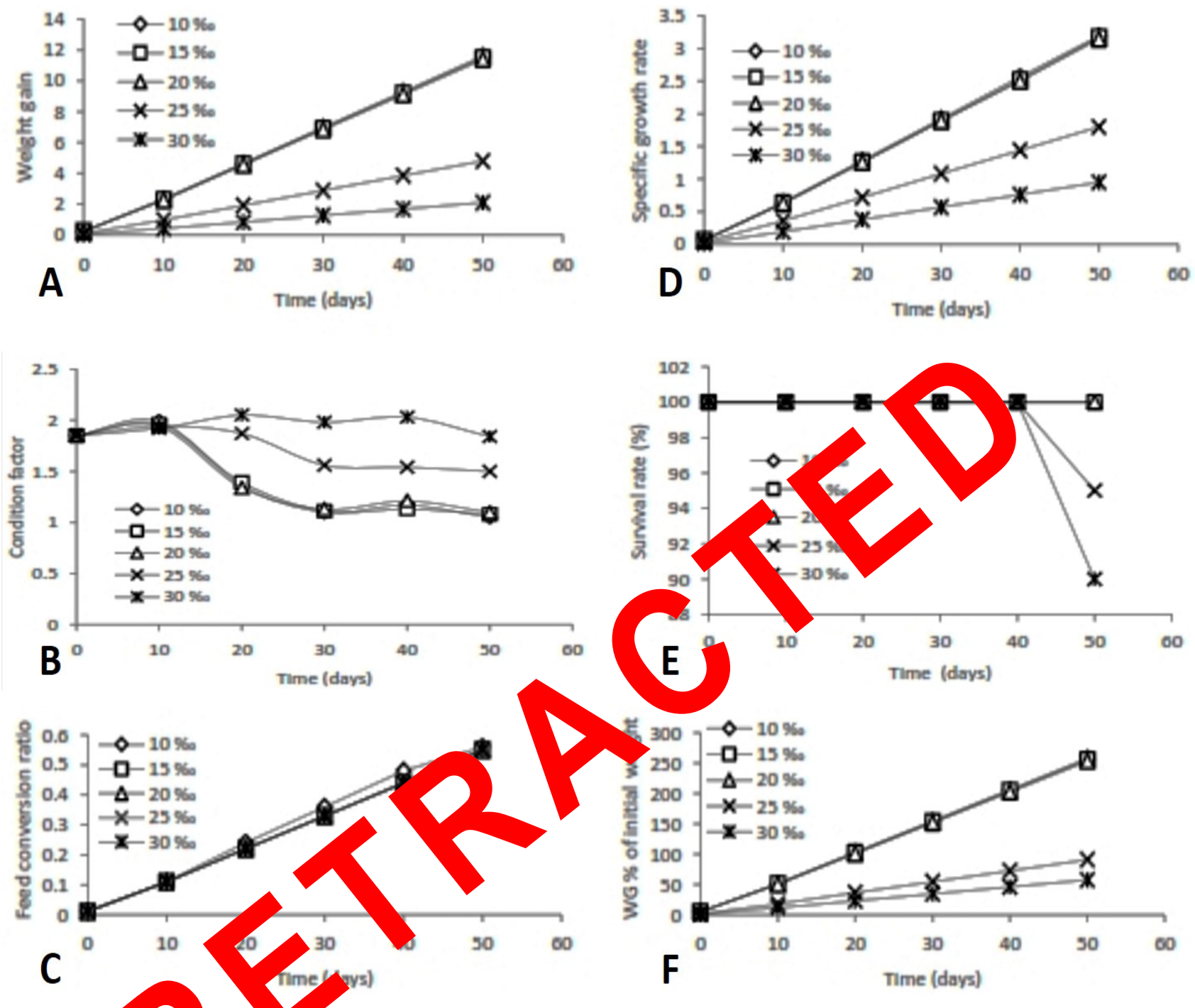

Fig. 1. Gru th thance of Nile tilapia in terms of weight gain (A), specific growth rate (B), condition factor (C), survival rate (D), feed con sion ratio (E) and weight gain, \% of initial weight (F) at different salinity levels for 50 days.

Dissolve oxygen (DO) of the tanks water was noticed by the help of portable test kit (Merck KGaA, 64271, Germany). The water $\mathrm{pH}$ was calculated by $\mathrm{pH}$ meter (EzDO 6011, Taiwan) and ammonia of the water was monitored with portable test kits (Merck KGaA, 64271, Germany) and salinity was observed by hand-held refractometer (Atago, S/Mill-E, 0.100\%o, made in Japan) on daily basis (Daudpota et al., 2016; Malik et al., 2018).

After 50 days of the completion of experiment, three fishes were caught from each tank and were frozen for chemical analysis. Fish body constituents like lipid, protein, ash, moisture etc were determined (AOAC, 2000). The data thus obtained was analyzed statistically by using statistical softwares like Minitab and SPSS (Zar, 1996).

\section{RESULTS AND DISCUSSION}

\section{Growth performance}

Weight gain (WG), specific growth rate (SGR) and survival of Nile tilapia ( $O$. niloticus) fingerlings reared at salinity level of $10 \%$ o to $20 \%$ was significantly $(P<0.05)$ higher than of those reared at 25\%o and 30\%o salinity (Fig. 1). Relationship of the salinity level with growth parameters was significantly $(P<0.05)$ higher up to $20 \%$ (Figs. 2 and 3). Similar results have been reported by Solomon and Okomoda (2012) while studying the effects of duckweed based diets given to O. niloticus. Evidence to support this is available in another study of Daudpota et al. (2016). They obtained best growth of Nile tilapia 
when reared at $10 \%$ salinity level with different feeding frequencies in seawater tanks. In the present study, specific growth rate (SGR) of the fish at 10\%o-20\%o was higher than the findings of Sallam et al. (2017). According to them, red tilapia showed good growth (SGR 0.56-0.85\%) at salinity ranging from $9 \%-36 \%$. These observations are advocated by Rahim et al. $(2017 \mathrm{a}, \mathrm{b})$ who described SGR (3.21\%) for black fin sea bream fed oil based diets at salinity level of $20 \%$. Moreover, Kapute et al. (2016) obtained maximum SGR (1.8\%) for Tilapia rendalli reared in $200 \mathrm{~m}^{2}$ brakishwater ponds. In addition, Abbas and Siddiqui (2009) reported SGR (0.9\% to $2.2 \%)$ of mangrove red snapper (Lutjanus argentimaculatus) cultured at salinity level of $35 \%$. Similar results were also reported by Solomon and Okomoda (2012) and Daudpota et al. (2016), showing that $O$. niloticus could efficiently culture up to $25 \%$ - $30 \%$ o salinity level. Feed conversion ratio (FCR) was found similar (0.55) among all salinity levels $(P<0.05)$ as shown in Figure 1 . These findings are in agreement with those reported in other studies, in terms of the possible culture of tilapia at different salinity level (Daudpota et al., 2014; Rahim et al., 2017a, b). However, another study of Daudpota et al. (2016) showed higher FCR (0.84) of red tilapia in concrete tanks as compared to the results of this research. Condition factor $(\mathrm{CF})$ was significantly $(P<0.05)$ higher at salinity level of $25 \%$ and $30 \%$ than those of $10 \%$ o to $2 \%$ Fig. 1) indicating wellbeing of the fingerlings at se lev

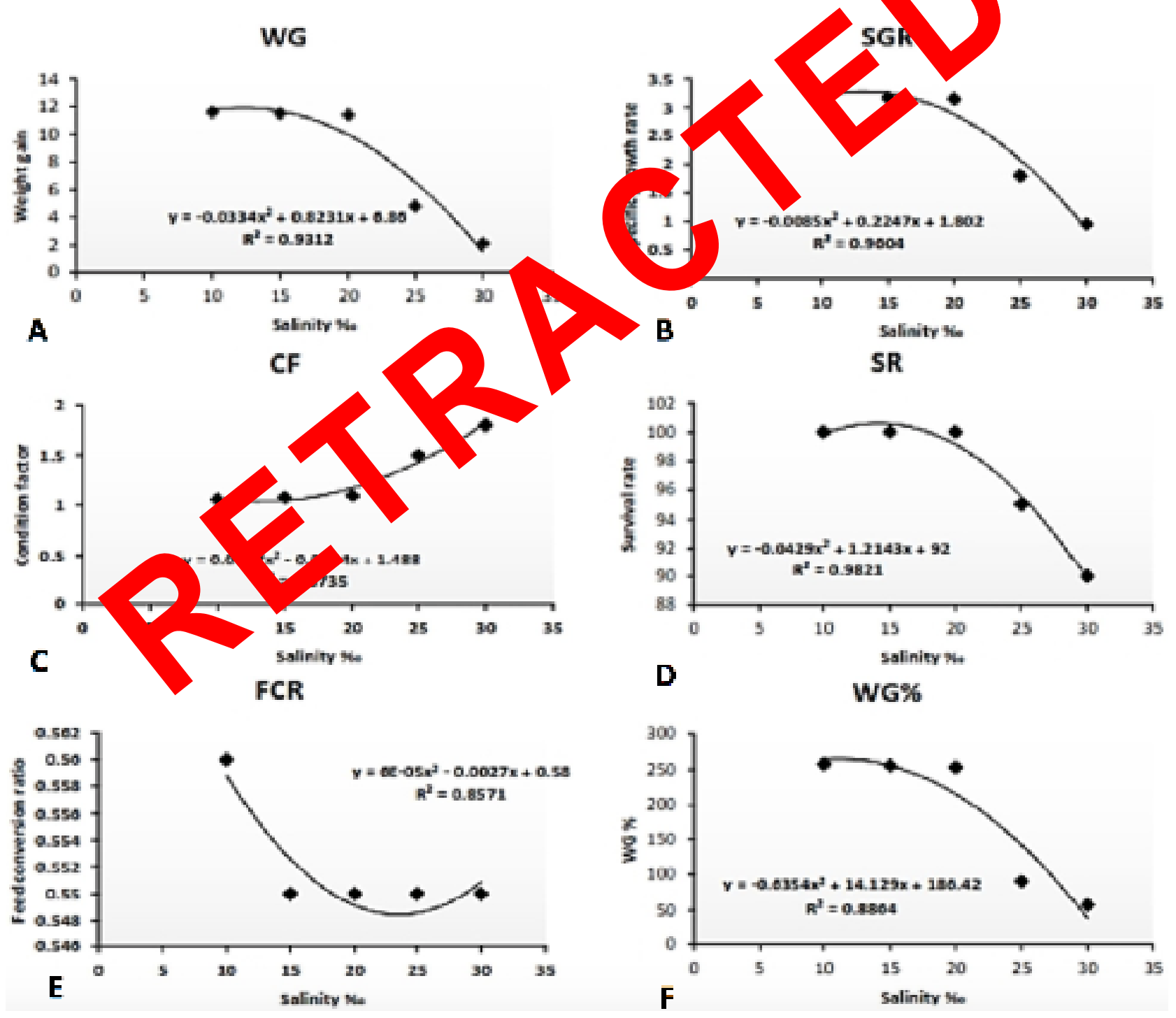

Fig. 2. Regression among the growth parameters of Nile tilapia in terms of weight gain (A), specific growth rate (B), condition factor (C), survival rate (D), feed conversion ratio (E) and weight gain, $\%$ of initial weight at different salinity levels for 50 days. 
A (10\%)

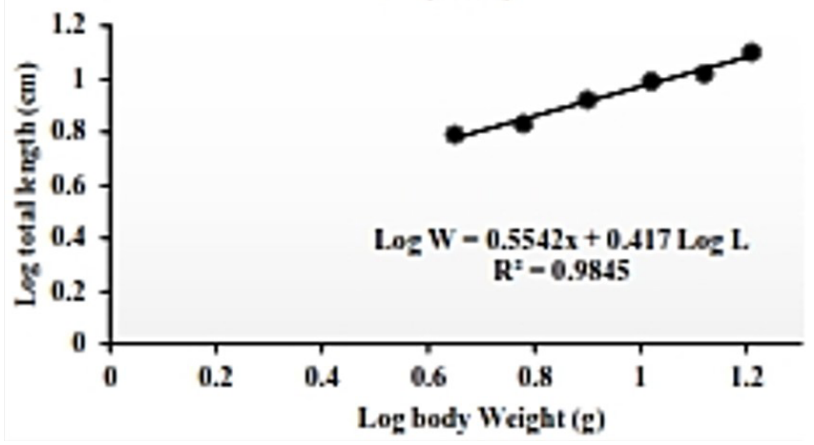

C (20\%)

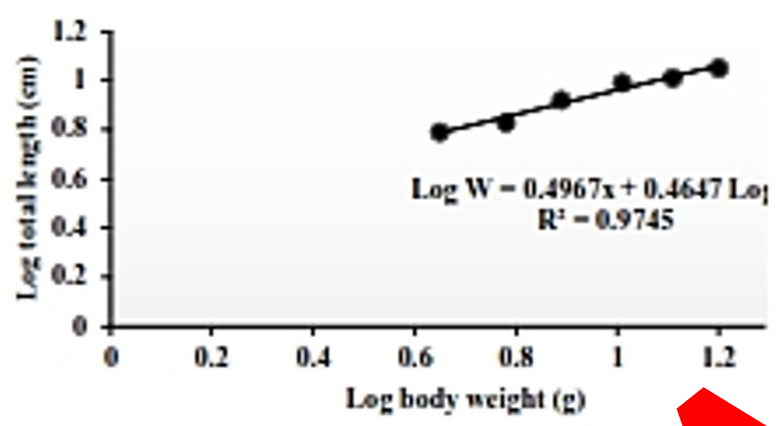

$B(15 \%)$
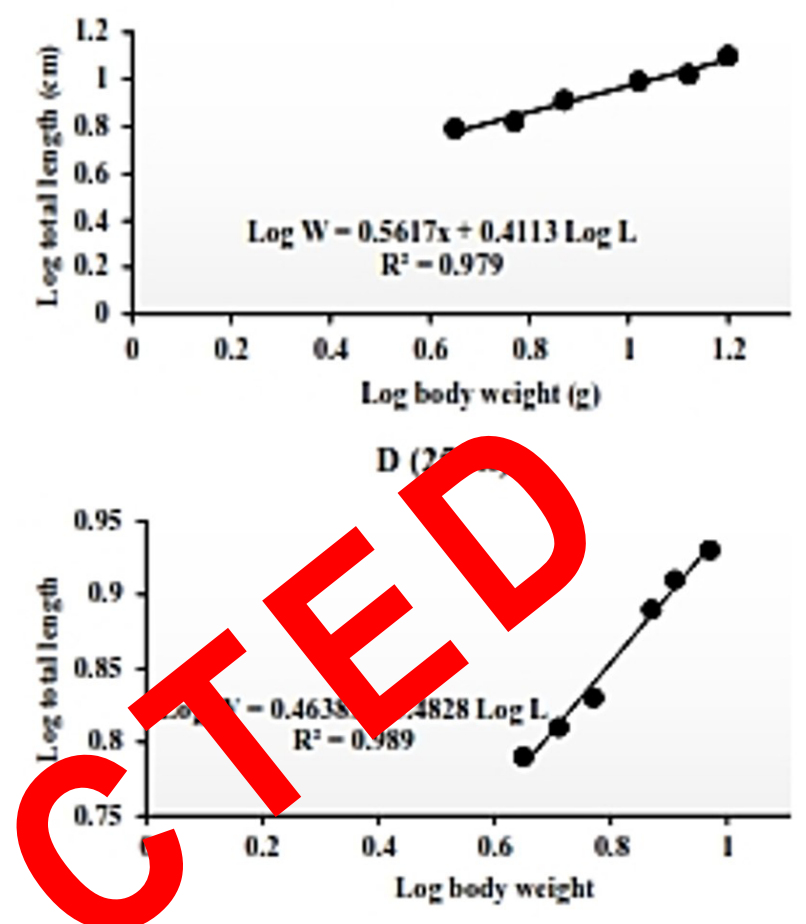

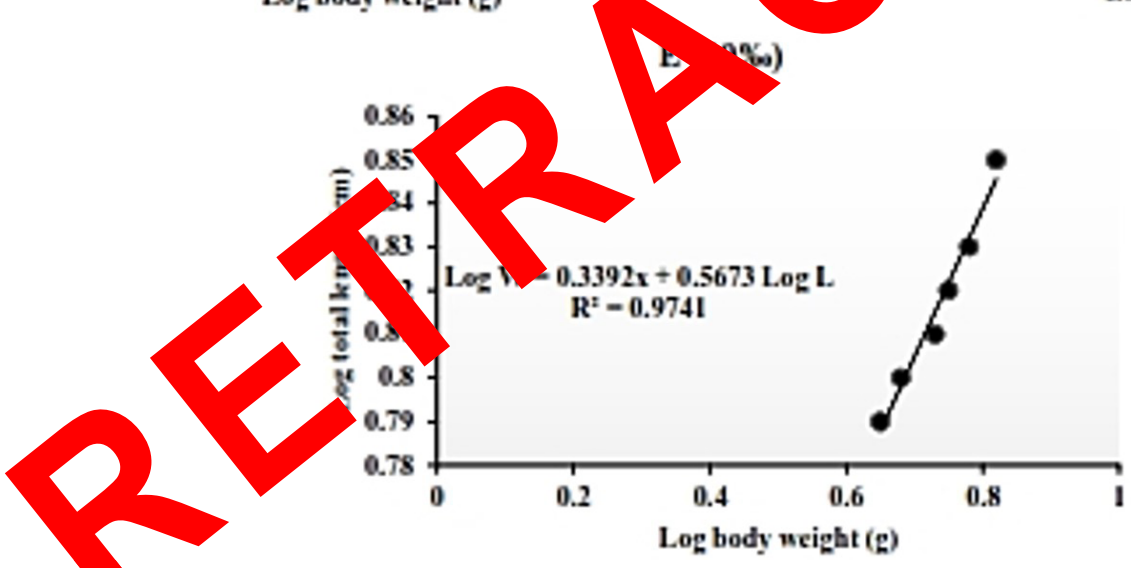

Fig. 3. Log total length $(\mathrm{cm})$ and log body weight $(\mathrm{g})$ relationship of Nile tilapia (Oreochromis niloticus) fingerlings reared at different salinity levels (A-E) for 50 days.

Table II.- Chemical composition of Nile tilapia (Oreochromis niloticus) reared at different salinity levels for 50 days.

\begin{tabular}{lccccc}
\hline Parameters & \multicolumn{5}{c}{ Salinity levels (\%) } \\
\cline { 2 - 6 } & $\mathbf{1 0}$ & $\mathbf{1 5}$ & $\mathbf{2 0}$ & $\mathbf{2 5}$ & $\mathbf{3 0}$ \\
\hline Protein (\%) & $53.16 \pm 0.2$ & $53.23 \pm 0.3$ & $53.18 \pm 0.4$ & $53.26 \pm 0.3$ & $53.23 \pm 0.2$ \\
Moisture (\%) & $71.16 \pm 0.2$ & $71.23 \pm 0.3$ & $71.18 \pm 0.4$ & $71.26 \pm 0.3$ & $71.23 \pm 0.2$ \\
Lipid (\%) & $2.52 \pm 0.12$ & $2.50 \pm 0.11$ & $2.51 \pm 0.12$ & $2.49 \pm 0.12$ & $2.50 \pm 0.11$ \\
Ash (\%) & $4.18 \pm 0.43$ & $4.18 \pm 0.43$ & $4.17 \pm 0.43$ & $4.17 \pm 0.42$ & $4.16 \pm 0.42$ \\
\hline
\end{tabular}

Values (Mean \pm SE, $\mathrm{n}=3$ and each $\mathrm{n}$ consists of 10 fish per replicate) in the same row with different superscripts are significantly different $(P>0.05)$. Chemical composition of initial body was: moisture $70.57 \%$, protein $52.21 \%$, lipid $2.49 .0 \%$ and ash $4.13 \%$. 
Table III.- Hematological parameters of juvenile Nile tilapia reared at different salinity levels for 50 days.

\begin{tabular}{lccccc}
\hline Parameters & \multicolumn{5}{c}{ Salinity level (\%o) } \\
\cline { 2 - 6 } & $\mathbf{1 0}$ & $\mathbf{1 5}$ & $\mathbf{2 0}$ & $\mathbf{2 5}$ & $\mathbf{3 0}$ \\
\hline Haematocrit $^{1}$ & $40.4 \pm 1.1^{\mathrm{a}}$ & $40.1 \pm 3.2^{\mathrm{a}}$ & $40.3 \pm 2.3^{\mathrm{a}}$ & $40.1 \pm 2.2^{\mathrm{a}}$ & $40.1 \pm 3.2^{\mathrm{a}}$ \\
Total lipids $^{2}$ & $1275.4 \pm 46.1^{\mathrm{a}}$ & $1266.2 \pm 48.0^{\mathrm{a}}$ & $1223.2 \pm 36.7^{\mathrm{a}}$ & $1259.3 \pm 50.5^{\mathrm{ab}}$ & $1277.1 \pm 32.0^{\mathrm{a}}$ \\
Triglycerides $^{2}$ & $143.5 \pm 56.1^{\mathrm{a}}$ & $146.1 \pm 51.1^{\mathrm{a}}$ & $149.2 \pm 52.6^{\mathrm{a}}$ & $147.9 \pm 42.2^{\mathrm{a}}$ & $145.8 \pm 58.2^{\mathrm{a}}$ \\
Cholesterol $^{2}$ & $142.4 \pm 50.2^{\mathrm{a}}$ & $145.5 \pm 49.5^{\mathrm{a}}$ & $146.2 \pm 56.3^{\mathrm{a}}$ & $144.4 \pm 47.9^{\mathrm{a}}$ & $143.0 \pm 50.5^{\mathrm{a}}$ \\
\hline
\end{tabular}

Values (Mean \pm SE, $n=3$ ) in the same row with similar superscripts are not significantly different $(P>0.05)$. Initial fish blood analysis was: hematocrit

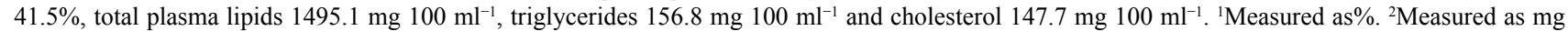
$100 \mathrm{ml}^{-1}$.

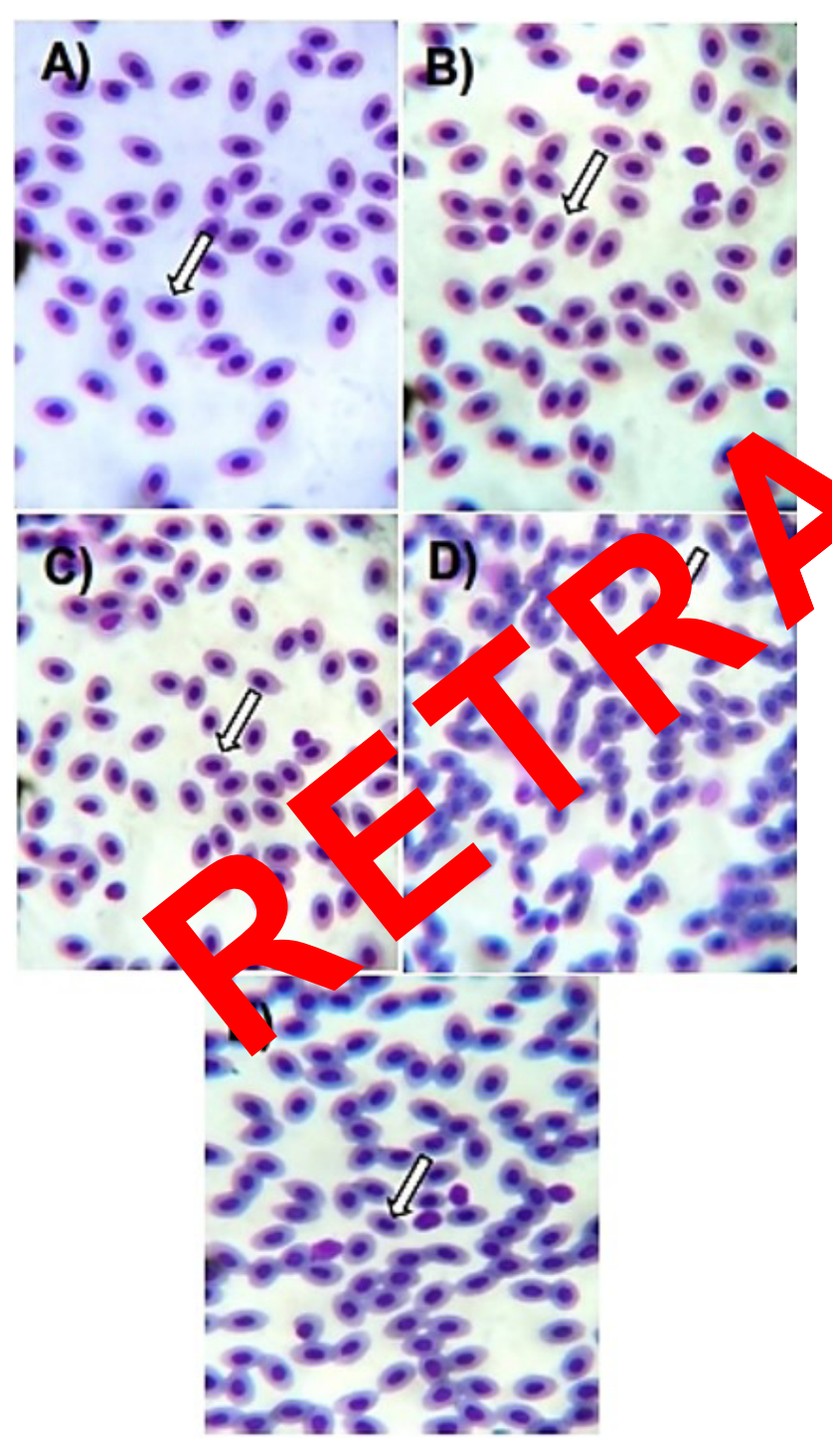

Fig. 4. Blood smear of Nile tilapia fingerlings (Oreochromis niloticus) reared on different salinity levels $(\mathrm{A}=15 \%$, $\mathrm{B}=20 \%, \mathrm{C}=25 \%$, $\mathrm{D}=30 \%$, $\mathrm{E}=35 \%$ ). Arrow, micronucleus (Giemsa stained: 1000X).

\section{Body composition and hemato}

The protein conten $53.16-53.26 \%$ ), moisture $(71.16 \%-71.26 \%)$, linid ( $9 \%-2$. \%), ash $(4.16 \%-$ $4.18 \%$ ) content of in whole dy re not significantly $(P>0.05)$ differen no reatme, groups (Table II) as has been noted other hes (D) udpota et al., 2014; Kapute et al., R Rahim e 2017a, b). Generally, blood is considered a nportant tool for carrying metabolites and ants inclu $g$ inorganic ions and blood chemistry $s$ used for the evaluation of an organism (Osuigwe and biekez 2007; Abbas and Siddiqui, 2009, 2013). In th ht study, hematological parameters did not show any disorder in blood smears of the fish reared at different alinity levels (Table III; Fig. 4). Similar trend has been reported in mangrove red snapper (Abbas and Siddiqui, 2009, 2013) and flounder (Daniels and Gallagher, 2000).

\section{Water quality}

Water quality in farming system is important for regulating fish metabolism, feed intake efficiency and survival rate of fish (Ertan et al., 2015). In the present study, water quality parameters like temperature, dissolved oxygen (DO), $\mathrm{pH}$ and ammonia were monitored on daily basis throughout the study period. Water temperature was recorded as $28.42 \pm 0.08^{\circ} \mathrm{C}$ (Fig. 5). DO remained as $7.48 \pm 0.06 \mathrm{mg} / \mathrm{L}$ and water $\mathrm{pH}$ was $7.64 \pm 0.04$ (Fig. 5). Ammonia never exceeded $0.02 \pm 0.004 \mathrm{mg} / \mathrm{L}$ (Fig. 5). These values were in coincidence with the findings of Daudpota et al. (2014), Malik et al. (2014), Chughtai et al. (2015), Iqbal et al. (2014), Emmanuel et al. (2014) and Shah et al. (2014).

\section{CONCLUSION}

From the results given above, it is concluded that Nile tilapia, O. niloticus can be cultured up to $20 \%$ salinity level under the experimental conditions of the present study. Moreover, this specie is also recommended for sustainable aquaculture development as it has potential for growing in brackish water or saline areas. 


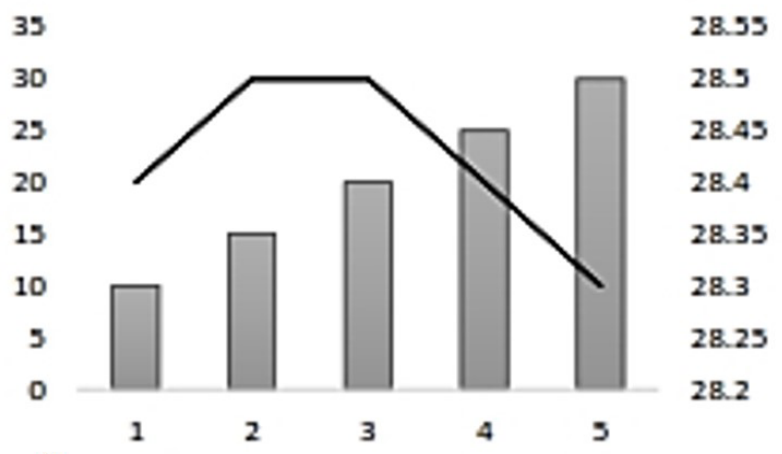

A
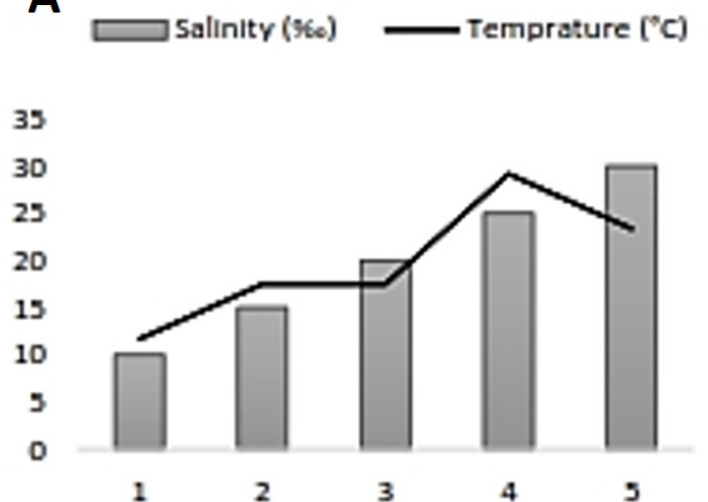

C

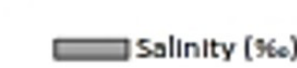

7.3

$\begin{array}{lr}28.55 & 35 \\ 28.5 & 30 \\ 28.45 & 25 \\ 28.4 & 20 \\ 28.35 & 15 \\ 28.3 & 10 \\ 28.25 & 5 \\ 28.2 & 0 \\ & \end{array}$

\section{B}
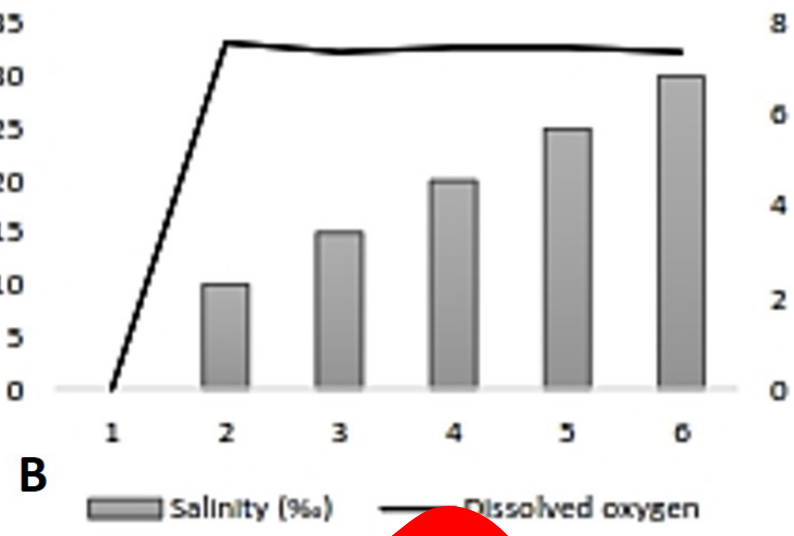

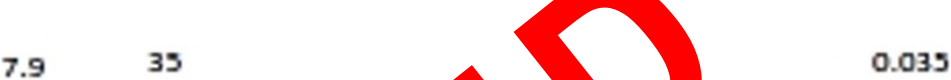

$7.830 \quad 0.03$

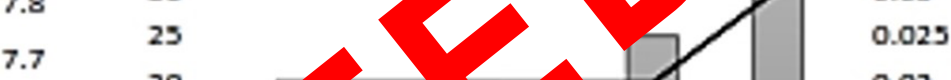

7.020

$7.5 \quad 15 \quad 0.015$

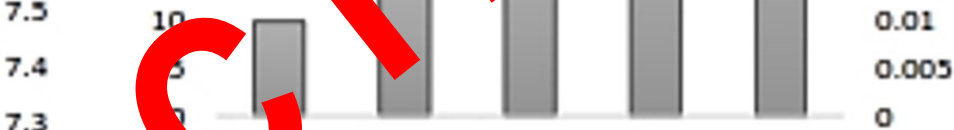

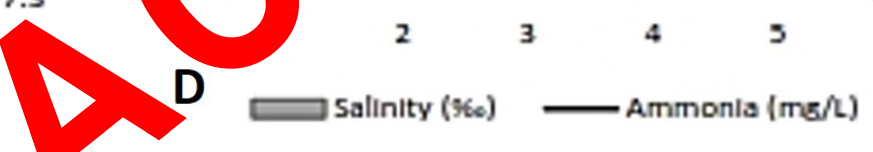

Fig. 5. Water quality parameters: A) temp ture C) B) di oolved oxygen, C) pH and D) ammonia of the experimental tanks.

\section{ACKNOWLF MENT}

The senior author grateful to the EC for providing fellowship to comple

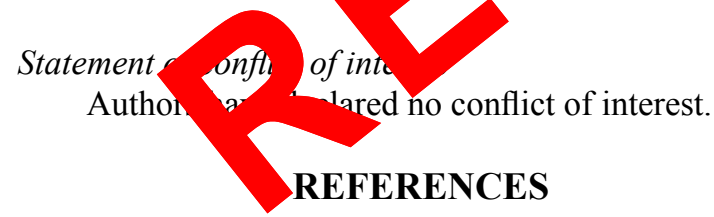

Abbas, G. and Siddiqui, P.J.A., 2009. Effect of different feeding levels on the growth, feed efficiency and body composition of juvenile mangrove red snapper, Lutjanus argentimaculatus (Forsskal 1775). Aquacult. Res., 40: 781-789. https://doi. org/10.1111/j.1365-2109.2008.02161.x

Abbas, G., Siddiqui, P.J.A. and Jamil, K., 2011. The optimal protein requirements of juvenile mangrove red snapper, Lutjanus argentimaculatus fed isoenergetic diets. Pakistan J. Zool., 44: 469-480.

Abbas, G. and Siddiqui, P.J.A., 2013. The effects of varying dietary protein level on growth, feed conversion, body composition and apparent digestibility coefficient of Juvenile Mangrove Red Snapper, Lutjanus argentimaculatus (Forsskal 1775). Aquacult. Res., 44: 807-818. https://doi. org/10.1111/j.1365-2109.2012.03096.x

Abdel-Tawwab, M., 2011. Natural food selectivity changes with weights of Nile tilapia (Oreochromis niloticus) reared in fertilized earthen ponds. J. appl. Aquacult., 23: 58-66. https://doi.org/10.1080/1045 4438.2011.549785

AOAC, 2000. Official methods of analysis of association of official analytical chemists, Vol. I. 17 $7^{\text {th }}$ edn. Association of Official Analytical Chemists, Arlington, USA, pp. 684.

Barlow, G.W., 2000. The Cichlid fishes: Nature's grand experiment in evolution. Perseus Publ., pp. 335.

Cao, L., Naylor, R., Henriksson, P., Leadbitter, D. and Metian, M., 2015. China's aquaculture and the world's wild fisheries. Science, 347: 133-135. https://doi.org/10.1126/science.1260149

Chughtai, M.I., Mahmood, K. and Awan, A.R., 2015. Growth performance of carp species fed on salttolerant roughages and formulated feed in brackish water under polyculture system, Pakistan J. Zool., 
47: 775-781.

Cnaani, A. and Hulata, G., 2011. Improving salinity tolerance in tilapia: Past experience and future prospects. Israeli J. Aquacult.Bamidgeh, 63: 533553.

Cressey, D., 2009. Aquaculture: future fish. Nature, 458: 398-400. https://doi.org/10.1038/458398a

Cruz, E.M., Rhidha, M. and Abdullah, M.S., 1990. Production of African freshwater tilapia $O$. spilurus (Gunther) in seawater. Aquaculture, 84: 41-48. https://doi.org/10.1016/0044-8486(90)90298-2

Daudpota, A.M., Abbas, G., Kalhoro, I.B., Shah, S.S.A., Kalhoro, H., Rehman M.H. and Gaffar, A., 2016. Effect of feeding frequency on growth performance, feed utilization and body composition of Nile tilapia, Oreochromis niloticus, cultured in low salinity water. Pakistan J. Zool., 48: 171-177.

Daudpota, A.M., Siddiqui, P.J.A., Abbas, G., Narejo, N.T., Shah, S.S.A., Khan, N. and Dastagir, G., 2014. Effect of dietary protein level on growth performance, protein utilization and body composition of Nile tilapia cultured in low salinity water. Int. J. Interdiscip. Multidiscip. Stud., 2: 135147.

Daniels, H.V. and Gallagher, M.L., 2000. Effect of dietary protein level on growth and bloo parameters in summer flounder, Paralichthys dentatus. J. appl. Aquacult. 10: 45-52. htps://dor. org/10.1300/J028v10n01

Dey, M.M., 2000. The impact of genetically improved farmed Nile tilapia in Asia. Aquacult. Econom. Manage., 4: 107-124. https://doi. org/10.1080/13657300009380263

El-Sayed, M.A., 2002. Effects of stocking density and feeding leyels on growth and feed efficiency of Nile tilapia (Oreochromis niloticus) fry. Aquacult. Res., 33: 621-626. https://doi.org/10.1046/j.13652109.2002.00700.x

El-Sayed, M.A., 2006. Tilapia culture in salt water: environmental requirements, nutritional implication and economic potentials. Avances en Nutrició Acuícola VIII. VIII Simposium internacional de Nutrición. Acuícola. Universidad Autónoma de Nuevo León, Monterrey, Nuevo León, Mexico, pp. 95-106. https://doi. org/10.1079/9780851990149.0000

Emmanuel, T.D.M., Felix, K.Y.A. and Ken, A., 2014. Comparative growth study of Oreochromis niloticus and Sarotherodon galilaeus under two different culture regimes (Hapa-In-Pond and cage systems). Int. J. Fish. aquat. Stud., 1: 53-59.

Ertan, E., Agrah, N. and Tarkan, A.S., 2015. The effects of salinity, temperature and feed ratio on growth performance of European sea bass (Dicentrarchus labrax L., 1758) in the water obtained through reverse osmosis system and a natural river. Pakistan J. Zool., 47: 625-633.

FAO, 2014. The state of World fisheries and aquaculture 2014. Rome, pp. 223.

Ferreira, J.G., Sequeira, A., Hawkins, A.J.S., Newton, A. and Nickell, T.D., 2009. Analysis of coastal and offshore aquaculture: application of the FARM model to multiple systems and shellfish species. Aquaculture, 289: 32-41. https://doi.org/10.1016/j. aquaculture.2008.12.0

Fitzsimmons, K.M., 2016. Global Tilapia market update 2015. In: WAS 2016. Las Vega

Githukia, C.M., Obiero, K.Q., Manyala, J.O., Ngugi, C. and Quagrainie, K., 2014. Consumer perceptions and preferences of wild and farmed Nile tilapia (Oreochromis niloticus L.) and African catfish in urban centers in Kenya. Int. J. Adv. Res., 2: 694705.

Hassan, M., Zakariah, M.I., Wahab. W., Muhammad, S.D. and Idris, N., 2013. Histopathological and ehavioral changes in Oreochromis sp. after exposure to different salinities. J. Fish. Livest. Prod., 1: 103.

Hernandez, M., Leyva, E.G. and Milstein, A., 2014. Polyculture of mixed-sex and male populations of Nile tilapia (Oreochromis niloticus) with the Mayan cichlid (Cichlasoma urophthalmus). Aquaculture, 26-31: 418-419.

Iqbal, R., Ali, M., Narejo, N.T. and Umar, K., 2014. Effect of varying levels of protein from different animal sources on growth and survival of carp, Cirrhinus mrigala, reared in cemented cisterns. Pakistan J. Zool., 46: 1599-1604.

Jeanette, C.F., Amy, K., Liza, M., Larry, G.R., Paul, H.Y., 2007. Effects of environmental salinity and temperature on osmoregulatory ability, organic osmolytes, and plasma hormone profiles in the Mozambique tilapia (Oreochromis mossambicus). Comp. Biochem. Physiol. A Mol. Integr. Physiol., 146: 252-264. https://doi.org/10.1016/j. cbpa.2006.10.027

Jeremy, S., Timothy, D.L., Stecko, J., Stauffer, R. and Carline, F.R., 1996. Combined effects of water temperature and salinity on growth and feed utilization of juvenile Nile tilapia (Oreochromis niloticus). Aquaculture, 146: 37-46. https://doi. org/10.1016/S0044-8486(96)01360-9

Kamal, A.M. and Mair, G.C., 2005. Salinity tolerance in superior genotypes of tilapia, Oreochromis 
niloticus, Oreochromis mossambicus and their hybrids. Aquaculture, 247: 189-201. https://doi. org/10.1016/j.aquaculture.2005.02.008

Kang'ombe, J. and Brown, J.A., 2008. Effect of salinity on growth, feed utilization, and survival of Tilapia rendalli, under laboratory conditions, J. appl. Aquacult., 20: 256-271. https://doi. org/10.1080/10454430802498229

Kapute, F., Valeta, J., Likongwe, J., Kang'ombe, J., Nagoli, J. and Mbamba, D., 2016. Growth performance of three tilapia fish species raised at varied pond sizes and water depths. Int. J. Fish. Aquacult., 8: 81-86. https://doi.org/10.5897/ IJFA2016.0566

Lawson, E.O. and Anetekhai, M.A., 2011. Salinity tolerance and preference of hatchery reared Nile Tilapia, Oreochromis niloticus (Linnaeus 1758). Asian J. agric. Sci., 3: 104-110.

Lim, C. and Webster, C.D., 2008. Tilapia: biology, culture, and nutrition. Afr. aquat. Sci., 33: 103. https://doi.org/10.2989/AJAS.2008.33.1.14.415

Malik, A., Waryani, B., Kalhor, I.B., Kalhoro, H., Shah, S.A. and Narejo, N.T., 2014. To observe the effect of growth performance and adaptation of exotic fish red tilapia (hybrid) in climate of Fish Hatchery Chilya, Thatta, Sindh-Pakistan. Sindh Univ. Res. (Sci. Ser.), 46: 461-464.

Malik, A., Abbas, G., Ghaffar, A., Ferrando, S. and Gallus, L., 2018. Impact of different salinity levels on growing performance, food conversion and meat quality of red tilapia (Oreochromis sp.) reared in seawater tanks. Pakistan J. Zool., 50: 409-415. http://dx.doi.org/10.17582/journal. pjz/2018.50.2.409.415

Mancera, J.M. and McCormick, S.D., 2007. Role of prolactin, growth hormone, insulin like growth factor $\mathrm{I}$ and cortisol in teleost osmoregulation. Fish Osmoregulation, Science Publishers, Enfield, NH, pp. 497-515.

Martins, C.I.M., Eding, E.H., Verdegem, M.C.J., Heinsbroek, L.T.N. and Schneider, O., 2010. New developments in recirculating aquaculture systems in Europe: A perspective on environmental sustainability. Aquacult. Eng., 43: 83-93. https:// doi.org/10.1016/j.aquaeng.2010.09.002

Mateen, A. and Iftikhar A., 2017. Effect of androgen on the sex reversal, growth of Nile tilapia, Oreochromis niloticus. Pak. J. agric. Sci., 44: 272-276.

Naylor, R.L., Goldburg, R.J., Primavera, J.H., Kautsky, N. and Beveridge, M.C.M., 2000. Effect of aquaculture on world fish supplies. Nature, 405: 1017-1024. https://doi.org/10.1038/35016500
Nelson J.S., 2006. Fishes of the World, $4^{\text {th }}$ Edition. John Wiley \& Sons, Inc., pp. 625.

Ng, W.K. and Romano, N., 2013. A review of the nutrition and feeding management of farmed tilapia throughout the culture cycle. Rev. Aquacult., 5: 220-254. https://doi.org/10.1111/raq.12014

Nguyen, N.H., 2016. Genetic improvement for important farmed aquaculture species with a reference to carp, tilapia and prawns in Asia: achievements, lessons and challenges. Fish Fisher., 17: 483-506. https:// doi.org/10.1111/faf.12122

OECD/FAO, 2015. Agricultural Outlook 2015. OECD Publishing, Paris, pp.

Ogello, E.O., Musa, S., Aura, C.M., Abwao, J.O. and Munguti, J., 2014. A critical appraisal of feasibility of tilapia production in earthen ponds using biofloc technology, a review. Int. J aquat. Sci., 5: 21-39.

Osuigwe, D.I. and Obiekezie, A.I., 2007. Assessment growth performance and feed utilization of fingerling Heterobrenchus longifilis fed raw, and boiled jackbean (Canavalia ensiformis) seed meal as fishmeal substitute. J. Fish. Int., 2: 37-41. https:// doi.org/10.1111/j.1753-5131.2010.01041.x M.L., 2007. Climate Change 2007-Impacts, adaptation and vulnerability: Working group II contribution to the fourth assessment report of the IPCC, Vol. 4. Cambridge University Press.

Ponzoni, R.W., Nguyen, H.N., Khaw, H.L., Hamzah, A. and Abu-Bakar, K.R., 2011. Genetic improvement of Nile tilapia (Oreochromis niloticus) with special reference to the work conducted by the World Fish Center with the GIFT strain. Rev. Aquacult., 3: 2741.

Rahim, A., Abbas, G., Gallus, L., Ferrando, S., Hafeezur-Rehman, M., Ghaffar, A. and Mateen, A., 2017. Effect of ration level and feeding frequency on growth, nutrient utilization and body composition of juvenile black fin Sea bream, Acanthopagrus berda (Forsskal 1775). Pakistan J. Zool., 49: 557-563. https://doi.org/10.17582/journal. pjz/2017.49.2.557.563

Rahim, A., Abbas, G., Naeem, M., Ferrando, S., Gallus, L., Hafeez-ur-Rehman, M., Ghaffar, A. and Mateen, A., 2017. Effect of different oils on growth, feed conversion and body composition of juvenile black fin Sea bream, Acanthopagrus berda (Forsskal 1775). Pakistan J. Zool., 49: 655-661. https://doi. org/10.17582/journal.pjz/2017.49.2.655.661

Saikia, S.K. and Das, D.N., 2015. Sustainable aquaculture: Agro-ecological role of and global overview. FAO, Rome, Italy. Periphyton in rice fish farming. Rev. Aquacult., 7: 172-186. https://doi. 
org/10.1111/raq. 12062

Sakamoto, T. and McCormick, S.D., 2006. Prolactin and growth hormone in fish osmoregulation. Gen. Comp. Endocrinol., 147: 24-30. https://doi. org/10.1016/j.ygcen.2005.10.008

Sallam, G.R., Fayed, W.A., El-Absawy, M.A., Aly, H.A. and El-Greisy, Z.A., 2017. Red tilapia broodstocks and larval production under different water salinities without acclimation. J. Aquacult. Res. Dev., 8: 476. https://doi.org/10.4172/2155-9546.1000476

Shah, S.A., Malik, A., Kalhoro, H., Kalhoro, I.B., Wadhar G.M. and Maher, G.M., 2014. Growth performance of exotic catfish Pangas, Pangasius hypophthalmus (Sauvage, 1878) at Fish Hatchery Chilya Thatta, Sindh Pakistan. Sindh Univ. Res. J. (Sci. Ser.), 46: 205-208.

Siddik, M.A.B., Nahar, A., Ahmed, F. and Hossain, M.Y., 2014. Over-wintering growth performance of mixed-sex and mono-sex Nile tilapia (Oreochromis niloticus) in Northeastern Bangladesh. Croatian J. Fish., 72: 70-76. https://doi.org/10.14798/72.2.722

Solomon S.G and Okomoda V.T., 2012. Growth performance of Oreochromis niloticus fed duckweed (Lemna minor) based diet in outdoor hapas. Int. J. Res. Fish. Aquacult., 2:61-65.

Stickney, R.R., 1986. A review of tilapia salinity tolerance. Progr. Fish-Cultur, 48: 161-167. https://doi.org/10.1577/15488640(1986)48<161:TTOSW $>2.0 . \mathrm{CO} ; 2$

Wassmann, R., Hien, N.X., Hoanh, C.T. and Tuong, T.P., 2004. Sea level rise affecting the Vietnamese Mekong Delta: Water elevation in the flood season and implications for rice production. Climatic Change, 66: 89-107. https://doi.org/10.1023/ B:CLIM.0000043144.69736.b7

Watanabe, W.O., Clark, J.H., Dunham, J.B., Wicklund, R.I. and Olla, B.L, 1990. Culture of Florida red tilapia in marine cages: the effect of stocking density and dietary protein on growth. Aquaculture, 90: 123-134. https:/doi.org/10.1016/0044848

Yue G.H., Lin, H.R. and Li, J.L., 2016. Tilapia is the fish for next-generation aquaculture. Int. J. Mar. Sci. Ocean Technol., 3: 11-13.

Zar, J.H., 1996. Bio-statistical analysis. Prentice-Hall

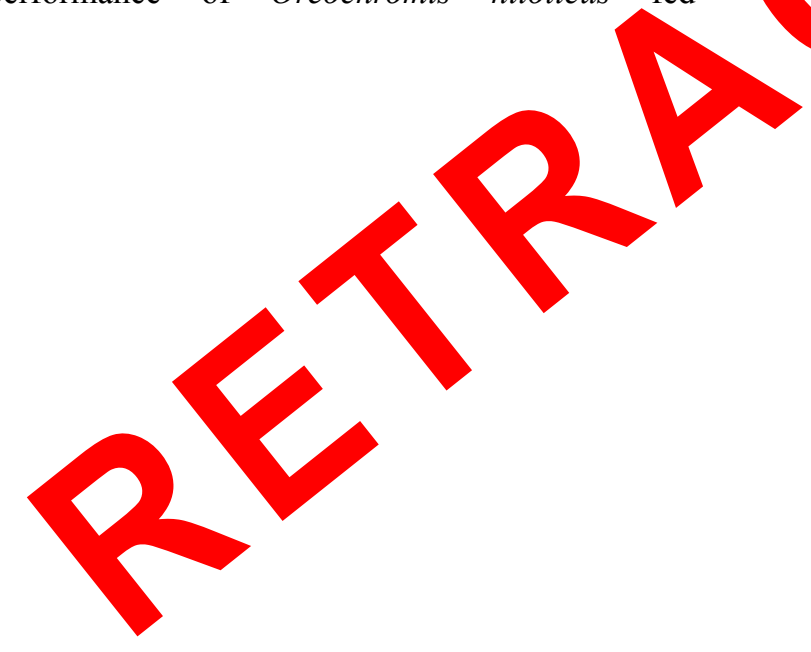

Inc., New Jersey, pp. 662. 